\title{
Antioxidative metabolism in sugarcane (Poaceae) varieties subjected to water and saline stress
}

\author{
Marciana B. de Morais ${ }^{1}$, Ricardo A. Azevedo ${ }^{2}$, Terezinha R. Camara ${ }^{3}$, Cláudia Ulisses ${ }^{3}$, \\ Cynthia C. de Albuquerque ${ }^{1} \&$ Lilia Willadino ${ }^{3}$
}

\begin{abstract}
${ }^{1}$ Universidade do Estado do Rio Grande do Norte/Programa de Pós-Graduação em Ciências Naturais. Mossoró, RN, Brasil. E-mail: marciana.bio@gmail.com (Corresponding author) - ORCID: 0000-0001-5074-5244; cycavalcanti@gmail.com - ORCID: 0000-0002-0959-1404

${ }^{2}$ Universidade de São Paulo/Escola Superior de Agricultura “Luiz de Queiroz"/Departamento de Genética. Piracicaba, SP, Brasil. E-mail: raa@usp.br ORCID: 0000-0001-7316-125X

${ }^{3}$ Universidade Federal Rural de Pernambuco/Departamento de Biologia. Recife, PE, Brasil. E-mail: teca.camara@gmail.com - ORCID: 0000-0003-33015535; claulisses@gmail.com - ORCID: 0000-0001-9723-5057; willadino.lilia@gmail.com - ORCID: 0000-0003-0491-4443
\end{abstract}

\begin{abstract}
This study aimed to identify the antioxidant responses of sugarcane (Saccharum spp.) varieties subjected to water and saline stress. Sugarcane seedlings of six different varieties obtained through micropropagation were subjected to either water or saline stress, or a combination of water + saline stress. The study was carried out in May 2012, in a greenhouse at the Universidade Federal Rural de Pernambuco (UFRPE). The experimental design was randomized, with treatments arranged in a $6 \times 4$ factorial scheme (six varieties and four treatments), and four replicates. Lipid peroxidation, hydrogen peroxide $\left(\mathrm{H}_{2} \mathrm{O}_{2}\right)$ concentrations, and relative water content (RWC) were evaluated. Furthermore, we evaluated the plants' antioxidative defense systems by measuring the activities of superoxide dismutase (SOD), ascorbate peroxidase (APX), and catalase (CAT). The sugarcane varieties had higher lipid peroxidation and/or higher $\mathrm{H}_{2} \mathrm{O}_{2}$ concentrations when subjected to the combined water + saline stress. The antioxidant enzymes responded to the water and saline stress treatments differently depending on the sugarcane variety. However, under combined saline + water stress conditions, the enzymes may have become inactivated, which indicates that the response to the combined water + saline stress was different from the sum of the responses to only water stress or only saline stress. High concentrations of malondialdehyde (MDA) associated with low RWC may be an effective indicator of multiple stress sensitivity in sugarcane varieties. The RB99395 and RB867515 sugarcane varieties responded more efficiently to environmental stress, and maintained their cell water content when subjected to either water or saline stress.
\end{abstract}

Key words: Sachorum, oxidative stress, defense system, ROS

\section{Metabolismo antioxidativo em variedades de cana-de-açúcar sob estresse hídrico e salino}

RESUMO: Objetivou-se com este trabalho identificar a resposta antioxidante de variedades de cana-de-açúcar sob condições adversas. Mudas de seis genótipos, procedentes da micropropagação, foram submetidas à avaliação da ação isolada e combinada do estresse hídrico e salino. A pesquisa foi realizada em maio de 2012, em casa de vegetação instalada na Universidade Federal Rural de Pernambuco (UFRPE). O delineamento experimental foi o inteiramente casualizado, com tratamentos dispostos em esquema fatorial $6 \times 4$ (seis variedades e quatro condições de cultivo) com quatro repetições. Avaliou-se a peroxidação lipídica, o teor de peróxido de hidrogênio $\left(\mathrm{H}_{2} \mathrm{O}_{2}\right)$, o teor relativo de água (TRA) e ação do sistema de defesa antioxidativo mediante a atividade das enzimas superóxido dismutase (SOD), ascorbato peroxidase (APX) e catalase (CAT). As variedades de cana-de-açúcar exibiram maior peroxidação lipídica e/ou maior concentração de peróxido de hidrogênio quando submetidas ao estresse combinado. As enzimas apresentaram respostas diferenciadas de acordo com a variedade de cana-de-açúcar e a intensidade de estresse nos tratamentos isolados, no entanto, podem ter sido inativadas perante o estresse combinado, o que indica que a resposta do estresse combinado é diferente da soma das respostas dos fatores abióticos aplicados isoladamente. Os elevados teores de malondialdeído (MDA) associados ao baixo TRA podem ser indicadores efetivos de sensibilidade a estresse múltiplo em variedades de cana-de-açúcar. As variedades RB99395 e RB867515 apresentaram-se mais eficientes quanto a resposta ao estresse ambiental e a manutenção de conteúdo hídrico celular nos estresses isolados.

Palavras-chave: Sochorum, estresse oxidativo, sistema de defesa, ROS 


\section{INTRODUCTION}

Sugarcane (Saccharum spp.) cultivation in the Northeastern region of Brazil has been expanding to semi-arid regions, exposing the crop to an environment more prone to the combination of abiotic stressors, such as salinity of water and soil, and water deficits during certain stages of sugarcane development, or even throughout the plant life cycle (Lyra et al., 2012). The irregular rainfall in drier areas, combined with the high evaporative demand, limits productivity (Silva et al., 2015), and becomes a limiting factor for crop expansion.

Exposure to one or several types of environmental stressors can increase the production of reactive oxygen species (ROS). ROS may lead to oxidative stress, which may cause partial or total oxidation of cell components, including membrane lipids and DNA, and may also result in photosynthetic damage by inducing changes in cell redox status (Morais et al., 2019). Because of the multifunctional effects of ROS, cells have a defense system against ROS. This complex system uses coordinated actions, and consists of a large number of hydrophilic antioxidant compounds and enzymatic components, as well as non-enzymatic components, which prevent oxidative damage and ROS accumulation, ensuring normal cell function (Soares et al., 2019).

The survival of plants under adverse conditions is a result of the evolution of adaptive mechanisms to cope with stress. Responses to stress are always associated with a series of physiological and biochemical responses at the cell level (Morais et al., 2018; Oliveira et al., 2019). In this respect, understanding the mechanisms of tolerance to environmental stressors in sugarcane is a challenge that should be addressed to inform the selection of more adapted cultivars, and achieve higher agricultural productivity. Therefore, the aim of this study was to assess the antioxidative system response of sugarcane varieties to the isolated and combined stresses caused by water deficits and salinity.

\section{Material ANd Methods}

An experimental approach was developed involving two different variables: water and saline stress. The experiment was conducted in a greenhouse, located in Recife, in the state of Pernambuco, in Northeastern Brazil ( $8^{\circ} 54^{\prime} 28^{\prime}$ ' S, 34 $52^{\circ}$ 53 " W). The study site was located $16 \mathrm{~m}$ above sea level, with average temperatures of $30.1 \pm 2.7^{\circ} \mathrm{C}$ during the day and $28.8 \pm$ $1.3^{\circ} \mathrm{C}$ at night, with a natural photoperiod, and a mean relative humidity $(\mathrm{RH})$ of $65 \pm 5.5 \%$.

Six "RB" (Republic of Brazil) varieties of micropropagated sugarcane plants cultivated for 60 days in plastic trays (with 50 square cells of $136 \mathrm{~mL}$ ) were obtained from SBW do Brasil Agrifloricultura Ltda. The six varieties were: RB966928, RB98710, RB855453, RB99395, RB867515, and RB855156, which will be referred to in this study as RB1, RB2, RB3, RB4, RB5, and RB6, respectively, for brevity. These varieties were reported to be either tolerant or sensitive to multiple stressors by Morais et al. (2018).

Plants were maintained in a greenhouse, and grown in coneshaped plastic tubes, with a capacity of $115 \mathrm{~cm}^{3}$, containing washed sand. After 15 days of acclimatization, the plants were divided into two groups. Plants in the first group were irrigated daily with Hoagland and Arnon nutrient solution (Hoagland \& Arnon, 1950) at half ionic strength. Plants in the second group received nutrient solution plus $\mathrm{NaCl}$ at a $50 \mathrm{mM}$ concentration and electrical conductivity of approximately 5.8 $\mathrm{dS} \mathrm{m} \mathrm{m}^{-1}$. The experiment included four treatments. Plants in the first group were divided into treatment 1 (T1), which consistent of continuous irrigation and no exposure to $\mathrm{NaCl}$ (control), and treatment 2 (T2) which consisted of irrigation being interrupted on the ninth day and no exposure to $\mathrm{NaCl}$ (water stress). Plants in the second group were divided into treatment 3 (T3) which consisted of continuous irrigation with saline solution (saline stress), and treatment 4 (T4), which consisted of irrigation with saline solution being interrupted on the ninth day (saline + water stress). The experimental period lasted 12 days (nine days under saline stress and three days of water interruption), and the experimental design was completely randomized using a $6 \times 4$ factorial scheme (six varieties and four treatments), with four repetitions, each of which consisted of one plant per tube.

The relative water content (RWC) of sugarcane plants was determined following the method of Weatherley (1950). In each repetition, six samples were collected from the central region of the leaf, packed in ice, and immediately transferred to the laboratory. Fresh mass (FM) was determined using an analytical scale within a period of up to $2 \mathrm{~h}$ after excision. The samples were then kept in deionized water for $24 \mathrm{~h}$, and after removal of excess water on filter paper, the turgid mass (TM) was obtained. Subsequently, the samples were dried at $70{ }^{\circ} \mathrm{C}$ for $48 \mathrm{~h}$ to determine the dry mass (DM) of the tissue. The RWC values were determined using the following equation: $($ FM-DM) / (TM-DM) $\times 100$.

The hydrogen peroxide $\left(\mathrm{H}_{2} \mathrm{O}_{2}\right)$ concentration was quantified according to Alexieva et al. (2001). Fresh samples were ground with $0.1 \%$ trichloroacetic acid (TCA) $0.1 \%$ in a $1 \mathrm{~g} / 10 \mathrm{~mL}(\mathrm{w}: \mathrm{v})$ solution. Samples were centrifuged at $10,000 \times \mathrm{g}$ for $15 \mathrm{~min}$ at $4{ }^{\circ} \mathrm{C}$. The resulting supernatant $(200 \mu \mathrm{L})$ was transferred to a new tube, and $200 \mu \mathrm{L}$ of $100 \mathrm{mM}$ potassium phosphate buffer ( $\mathrm{pH} 7.5$ ) and $800 \mu \mathrm{L}$ of $1 \mathrm{M}$ potassium iodide were added. Samples were kept on ice and in the dark for $1 \mathrm{~h}$. Subsequently, samples were removed from ice and kept at room temperature for stabilization of the reaction, and samples were read in a spectrophotometer at $390 \mathrm{~nm}$.

Lipid peroxidation was evaluated according to the method of Heath \& Packer (1968), with modifications. The reaction was determined by the production of malondialdehyde (MDA), a metabolite reactive to 2-thiobarbituric acid (TBA). Biological samples $(0.2 \mathrm{~g})$ were ground in $2 \mathrm{~mL} 0.1 \%$ TCA, with buffer containing 20\% insoluble PVPP (polyvinylpolypyrrolidone). After homogenization, samples were centrifuged at $10,000 \times g$ for $5 \mathrm{~min}$. A $200 \mu \mathrm{L}$ aliquot from supernatant was transferred to other tube with $1.0 \mathrm{~mL}$ solution containing 20 and $0.5 \%$ TBA. The mixture was kept in a water bath at $95^{\circ} \mathrm{C}$ for $30 \mathrm{~min}$, and subsequently rapidly cooled for $10 \mathrm{~min}$. Samples were centrifuged for an additional $10 \mathrm{~min}$ at $10,000 \times \mathrm{g}$, and then read in a spectrophotometer at 535 and $600 \mathrm{~nm}$.

For protein extraction, frozen samples were ground and homogenized in $100 \mathrm{mM}$ potassium phosphate buffer ( $\mathrm{pH}$ 7.5), 
1 mM EDTA, 3 mM DTT, and 20\% insoluble PVPP on ice, in a $1 \mathrm{~g}: 3 \mathrm{~mL}^{-1}$ (w:v) ratio (Azevedo et al., 1998). Subsequently, the samples were centrifuged at $10,000 \times g$ for $30 \mathrm{~min}$, and the supernatant was separated into aliquots and stored at $-20{ }^{\circ} \mathrm{C}$ until the determination of enzymatic activities.

The total protein concentration was determined with the Bradford (1976) method, using bovine serum albumin (BSA) as a standard. The reaction was performed by adding $20 \mu \mathrm{L}$ of sample (previously diluted) to $1 \mathrm{~mL}$ of Bradford reagent, and incubating the mixture at room temperature for $5 \mathrm{~min}$.

The catalase (CAT) activity was determined using the method described by Havir \& McHale (1987), with modifications according to Azevedo et al. (1998). CAT activity was determined in a solution containing $1.5 \mathrm{~mL}$ $100 \mathrm{mM}$ potassium phosphate buffer $(\mathrm{pH} \mathrm{7.5)}$ and $60 \mu \mathrm{L}$ of $0.1 \mathrm{M} \mathrm{H}_{2} \mathrm{O}_{2}$. The reaction was started by adding $50 \mu \mathrm{L}$ protein extract, and the activity was determined following the $\mathrm{H}_{2} \mathrm{O}_{2}$ decomposition for $60 \mathrm{~s}$ at $25^{\circ} \mathrm{C}$, with sample absorbance read in a spectrophotometer at $240 \mathrm{~nm}$. Results were expressed as $\mu \mathrm{mol} \mathrm{mg} \mathrm{mg}^{-1}$ protein $\mathrm{min}^{-1}$, considering that one unit of CAT activity was able to decompose $1 \mu \mathrm{mol} \mathrm{H}_{2} \mathrm{O}_{2}$ per mg protein in $1 \mathrm{~min}$ at $\mathrm{pH} 7.5$.

The ascorbate peroxidase (APX) activity was determined as described by Nakano \& Asada (1981). The reaction medium was composed of $650 \mu \mathrm{L}$ potassium phosphate buffer $(80 \mathrm{mM}$, pH 7.5), $100 \mu \mathrm{L}$ ascorbate $(5 \mathrm{mM}), 100 \mu \mathrm{L}$ EDTA (1 M), 100 $\mu \mathrm{L} \mathrm{H}_{2} \mathrm{O}_{2}(1 \mathrm{mM})$, and $50 \mu \mathrm{L}$ protein extract. APX activity was determined by monitoring the ascorbate oxidation rate at 290 $\mathrm{nm}$ and at $30^{\circ} \mathrm{C}$ for $60 \mathrm{~s}$ in a spectrophotometer. Results were

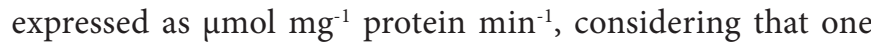
unit of APX activity was able to convert $1 \mu \mathrm{mol}$ ascorbic acid into monodehydroascorbate in $1 \mathrm{~min}$.

For the determination of superoxide dismutase (SOD) activity, we followed the protocol developed by Giannopolitis \& Ries (1977), with minor modifications. Using this method, the inhibition of nitro blue tetrazolium (NBT) reduction by enzymatic extracts was determined, thus avoiding the formation of the formazan chromophore. The reaction solution (3 mL) was composed of $85 \mathrm{mM}$ phosphate buffer ( $\mathrm{pH} 7.8$ ), 75 $\mu \mathrm{M}$ NBT, $5 \mu \mathrm{M}$ riboflavin, $13 \mathrm{mM}$ methionine, $0.1 \mathrm{mM}$ EDTA, and $50 \mu \mathrm{L}$ enzymatic extract. The solution was transferred to a glass tube and irradiated with white light (fluorescent $15 \mathrm{~W}$ lamp) for $5 \mathrm{~min}$. Subsequently, the solution was analyzed using a spectrophotometer at $560 \mathrm{~nm}$. One activity unit was defined as the amount of enzyme that inhibited $50 \%$ of formazan formation per gram of protein, with results expressed as $U \mathrm{mg}$ protein $^{-1}$. On day 12 of the experiment, sugarcane samples were collected, and part of the plant material was immediately frozen in liquid nitrogen and kept at $-20{ }^{\circ} \mathrm{C}$ until the biochemical analyses were performed.

Statistical analysis was carried out using repeated measures analysis of variance (Anova), followed by Scott-Knott tests, with a probability of $\mathrm{p} \leq 0.05$, using Sisvar 5.3 software (Ferreira, 2008). Relationship between the variables was determined by the correlation matrix, using the software ASSISTAT 7.7. Results demonstrated the existence of significant and positive correlation between some variables.

\section{Results AND Discussion}

The results of the analysis of variance (ANOVA) of the RWC, $\mathrm{H}_{2} \mathrm{O}_{2}$ concentration, and lipid peroxidation variables are shown in Table 1. Sugarcane varieties, experimental treatments, and the interaction between variety and treatment significantly affected sugarcane RWC, $\mathrm{H}_{2} \mathrm{O}_{2}$ concentrations, and lipid peroxidation. Water stress (T2) resulted in a lower RWC in all sugarcane varieties, with the lowest RWC (70\%) recorded in varieties RB2 and RB3 (Figure 1). Under saline stress (T3), the RWC values remained above $75 \%$, indicating that the sugarcane varieties experienced a moderate loss of water. The capacity of varieties RB4, RB5, and RB6 to cope with water loss, under conditions of water or saline stress, or combined water + saline stress, can be evidenced by RWC values. These varieties maintained a high RWC under the different treatments, which may be associated with tolerance to water and saline stress (Morais et al., 2018). On the other hand, when exposed to both water and saline stress (T4), the greatest losses of water occurred mainly in varieties RB1 and RB3, which had RWCs of approximately $65 \%$ and $56 \%$, respectively, demonstrating the severity of the combination of the two types of stress. The RWC is a crucial variable for the evaluation of plant water status (Morais et al., 2018). Previous research on different sugarcane varieties (HOCP85-845, TCP02-4587, TCP02-4620, and US01-40) indicated that lower reductions in RWC characterize stress-tolerant varieties (Silva et al., 2007).

Water scarcity is a factor that greatly limits the growth and development of several plant species, causing immediate loss of cell turgor (Afzal et al., 2014). Under conditions of water scarcity, plants tend to direct their resources to the mechanisms that support their survival, such as greater root development and leaf area reduction, which support greater water absorption through the soil and reduce water loss through transpiration, respectively (Ajithkumar \& Panneerselvam, 2014; Aranda et al., 2015; Silva-Pinheiro et al., 2016).

Abiotic stresses, such as saline and water stress, adversely affect plant development, and characteristics such as growth reduction have been described in varieties of sugarcane and other plant species exposed to such stresses (Cassaniti et al., 2012; Lira et al., 2018; Bezerra et al., 2019; Oliveira et al., 2019; Palhares Neto et al., 2019). However, the exact response to each type of stress varies greatly between species, and even between varieties (Cassaniti et al., 2012).

Table 1. Analysis of variance (ANOVA) of effects of sugarcane variety and treatments on sugarcane plants' relative water content (RWC), hydrogen peroxide $\left(\mathrm{H}_{2} \mathrm{O}_{2}\right)$ concentrations, and lipid peroxidation

\begin{tabular}{lcccc}
\hline \multirow{2}{*}{ SV } & DF & $\begin{array}{c}\text { Relative water } \\
\text { content }\end{array}$ & $\begin{array}{c}\text { Hydrogen } \\
\text { peroxide }\end{array}$ & $\begin{array}{c}\text { Lipidic } \\
\text { peroxidation }\end{array}$ \\
\cline { 3 - 5 } & & \multicolumn{3}{c}{ MS } \\
Variety - RB & 5 & $173.21^{* *}$ & $78.74^{* *}$ & $8.91^{* *}$ \\
\hline Treatment - T & 3 & $2662.74^{* *}$ & $30.62^{* *}$ & $17.94^{* *}$ \\
RB x T & 15 & $84.90^{* *}$ & $1.23^{*}$ & $1.72^{* *}$ \\
Error & 72 & 32.59 & 0.60 & 0.33 \\
Overall mean & & $80.4 \%$ & $5.68 \mu \mathrm{mol}$ & $3.49 \mathrm{nmol}$ \\
CV (\%) & & 7.09 & 13.64 & 16.49 \\
\hline
\end{tabular}

SV - Source of variation; DF - Degrees of freedom; MS - Mean square; ${ }^{*}$, ** - Significant at $\mathrm{p} \leq 0.05$ and $\mathrm{p} \leq 0.01$, respectively, according to the F test; CV - Coefficient of variation 
A.

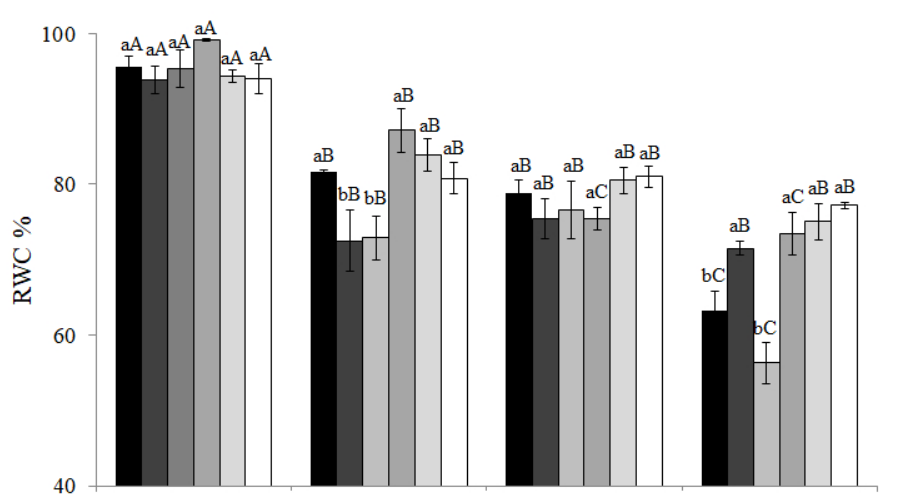

C.

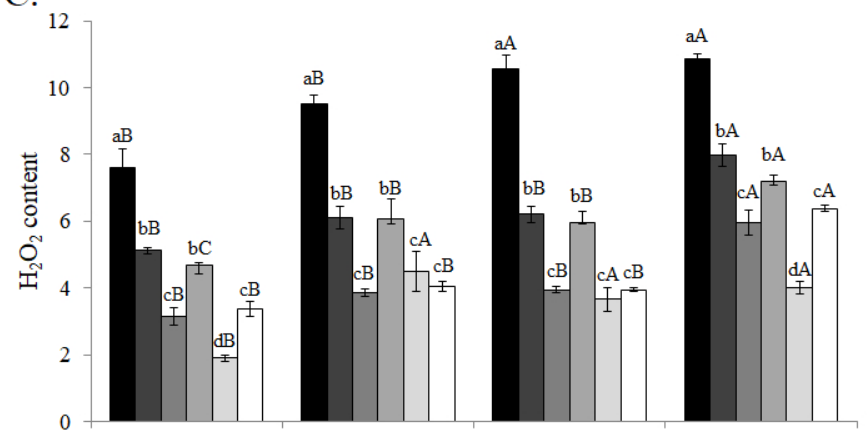

E.

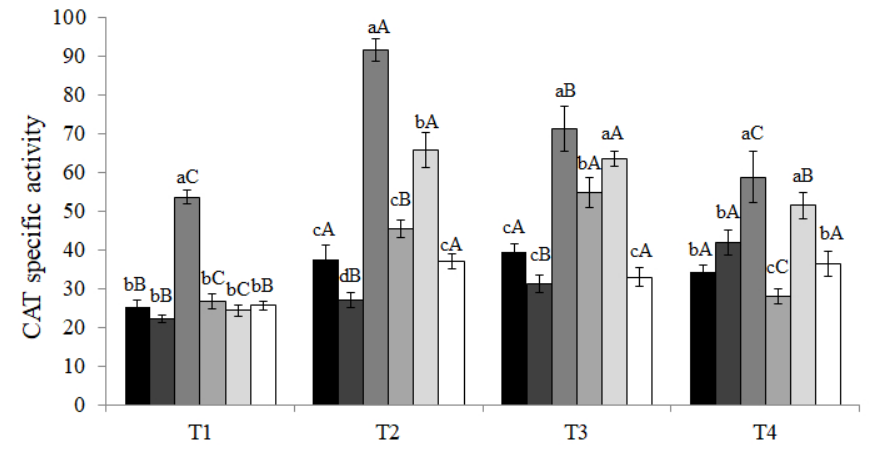

B.

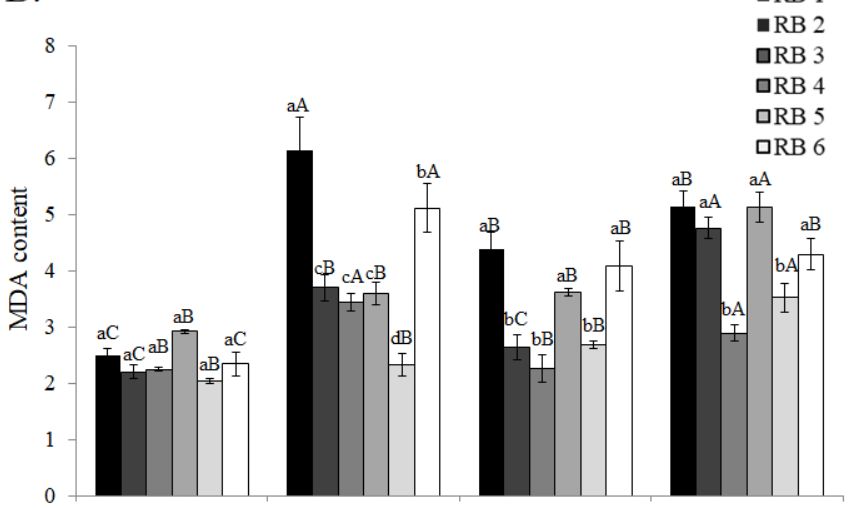

D. 90



F.

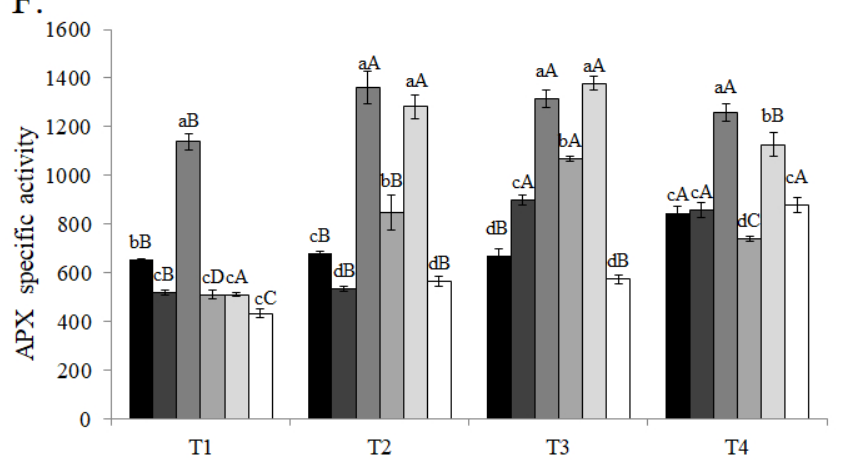

$\mathrm{T} 1$ - Treatment without $\mathrm{NaCl}$, with continuous irrigation (control); $\mathrm{T} 2$ - Treatment without $\mathrm{NaCl}$ with irrigation interrupted on the ninth day (water stress); $\mathrm{T} 3$ - Continuous irrigation with saline solution (saline stress); and T4 - Irrigation with saline solution interrupted on the ninth day (saline + water stress); The same lowercase letters between varieties undergoing the same treatment and upper-case letters between different treatments for the same variety do not differ from each other using the Scott-Knott test at $\mathrm{p} \leq 0.05$

Figure 1. Relative water content (RWC) (A); Lipid peroxidation expressed by the malondialdehyde (MDA) concentration $\left(\mathrm{nmol} \mathrm{g}{ }^{-1} \mathrm{FM}\right)(\mathrm{B})$; hydrogen peroxide $\left(\mathrm{H}_{2} \mathrm{O}_{2}\right)$ concentration $\left(\mu \mathrm{mol} \mathrm{g}^{-1} \mathrm{FM}\right)(\mathrm{C})$; superoxide dismutase $(\mathrm{SOD})$ activity (U SOD $\mathrm{mg}^{-1}$ protein) (D); catalase (CAT) activity ( $\mu \mathrm{mol} \mathrm{min}^{-1} \mathrm{mg}^{-1}$ protein) (E); ascorbate peroxidase (APX) activity ( $\mu \mathrm{mol} \mathrm{min}^{-1} \mathrm{mg}^{-1} \mathrm{f}$ protein) (F) in leaves of sugarcane varieties grown in greenhouse conditions under saline and water stress treatments

The RB1 variety had a low RWC, high levels of membrane damage (high MDA concentrations), and high $\mathrm{H}_{2} \mathrm{O}_{2}$ concentrations (Figures 1A, B and C). These characteristics were also observed by other authors in sugarcane varieties subjected to water and/or saline stress (Cia et al., 2012; Morais et al., 2018). High concentrations of MDA, together with low RWC during stress conditions can be effective indicators of sensitivity to multiple stresses in sugarcane varieties (Morais et al., 2018), since MDA is the result of a reaction between ROS and polyunsaturated fatty acids. The increase in MDA concentration, a peroxidation product of polyunsaturated fatty acids from biomembranes, is an important biomarker of oxidative stress (Morais et al., 2018). An increase in MDA concentrations may be indicative of antioxidant system failure (Tayebimeigooni et al., 2012), which causes electrolyte leakage and cell death. As such, peroxidation has been used as a marker in plant material selection (Lata et al., 2011; Morais et al., 2018).

In most sugarcane varieties, there was a highly negative correlation ( $\geq-0.5)$ between the RWC and $\mathrm{H}_{2} \mathrm{O}_{2}$ concentrations (Table 2), indicating the harmful effects of the accumulation of this reactive oxygen species. $\mathrm{H}_{2} \mathrm{O}_{2}$ is a signaling molecule; however, accumulation of $\mathrm{H}_{2} \mathrm{O}_{2}$ (Figure 1C) may have indirectly contributed to the peroxidation of membrane lipids, in both isolated and combined stress treatments (Figure 1B). Although $\mathrm{H}_{2} \mathrm{O}_{2}$ does not directly participate in lipid peroxidation, its reaction with ferrous ions $\left(\mathrm{Fe}^{2+}\right)$ leads to the formation of hydroxyl radicals $(\mathrm{OH} \bullet)$, which, together with singlet oxygen $\left({ }^{1} \mathrm{O}_{2}\right)$ cause degradation of membrane lipids (Sewelam et al., 2016). $\mathrm{Fe}^{2+}$ is a product of $\mathrm{Fe}^{3+}$ reduction by ${ }^{\circ} \mathrm{O}_{2}$. Therefore, an increase in SOD activity is an important mechanism that prevents the formation of $\mathrm{OH} \bullet$ (Morais et al., 2018), and can 
Table 2. Pearson's correlation for physiological and biochemical variables in leaves of sugarcane varieties subjected to water and saline stress treatments

\begin{tabular}{|c|c|c|c|c|c|c|c|c|c|c|c|c|}
\hline & CAT & APX & SOD & MDA & $\mathrm{H}_{2} \mathrm{O}_{2}$ & RWC & CAT & APX & SOD & MDA & $\mathrm{H}_{2} \mathrm{O}_{2}$ & RWC \\
\hline & \multicolumn{6}{|c|}{ RB1 } & \multicolumn{6}{|c|}{ RB2 } \\
\hline CAT & 1 & 0.37 & $0.79^{\star \star *}$ & $0.63^{\star *}$ & $0.50^{\star}$ & -0.41 & 1 & $0.70^{\star *}$ & 0.23 & $0.70^{* *}$ & $0.72^{\star \star}$ & -0.53 \\
\hline APX & & 1 & 0.22 & 0.49 & $0.77^{* *}$ & $-0.64^{* *}$ & & 1 & 0.48 & 0.30 & $0.58 *$ & -0.40 \\
\hline SOD & & & 1 & 0.49 & 0.35 & -0.39 & & & 1 & 0.03 & 0.11 & -0.33 \\
\hline MDA & & & & 1 & 0.48 & -0.49 & & & & 1 & $0.81^{* *}$ & $-0.67^{\star *}$ \\
\hline $\mathrm{H}_{2} \mathrm{O}_{2}$ & & & & & 1 & $-0.76^{\star \star}$ & & & & & 1 & -0.46 \\
\hline \multirow[t]{2}{*}{ RWC } & \multirow{2}{*}{\multicolumn{6}{|c|}{ RB3 }} & & & & & & 1 \\
\hline & & & & & & & \multicolumn{6}{|c|}{ RB4 } \\
\hline CAT & 1 & $0.68^{\star \star}$ & $0.87^{\star \star}$ & 0.40 & -0.09 & -0.18 & 1 & $0.82^{\star \star}$ & $0.66^{\star \star}$ & -0.19 & 0.05 & -0.26 \\
\hline APX & & 1 & 0.44 & 0.46 & 0.14 & -0.18 & & 1 & $0.88^{* *}$ & 0.11 & 0.23 & $-0.56^{*}$ \\
\hline SOD & & & 1 & 0.18 & -0.28 & -0.07 & & & 1 & 0.28 & 0.30 & $-0.72^{\text {** }}$ \\
\hline MDA & & & & 1 & 0.23 & -0.24 & & & & 1 & $0.64^{\star *}$ & $-0.64^{\star \star}$ \\
\hline $\mathrm{H}_{2} \mathrm{O}_{2}$ & & & & & 1 & $0.79^{* *}$ & & & & & 1 & -0.49 \\
\hline \multirow[t]{2}{*}{ RWC } & & & & & & 1 & & & & & & 1 \\
\hline & \multicolumn{6}{|c|}{ RB5 } & \multicolumn{6}{|c|}{ RB6 } \\
\hline CAT & 1 & $0.96^{\star \star}$ & $0.65^{\star \star}$ & 0.25 & 0.75 & $-0.58 *$ & 1 & -0.24 & -0.15 & -0.41 & -0.28 & 0.41 \\
\hline APX & & 1 & $0.69 * *$ & 0.33 & $0.76^{\star *}$ & $-0.65^{\star *}$ & & 1 & 0.18 & 0.38 & $0.96^{* *}$ & $-0.65^{* *}$ \\
\hline SOD & & & 1 & 0.05 & 0.34 & -0.20 & & & 1 & $0.67^{\star \star \star}$ & 0.15 & -0.26 \\
\hline MDA & & & & 1 & 0.35 & $-0.77^{\star \star}$ & & & & 1 & 0.31 & $-0.66^{\star \star}$ \\
\hline $\mathrm{H}_{2} \mathrm{O}_{2}$ & & & & & 1 & $-0.53^{*}$ & & & & & 1 & $-0.56^{\star}$ \\
\hline RWC & & & & & & 1 & & & & & & 1 \\
\hline
\end{tabular}

RWC - Relative water content; MDA - Malondialdehyde; Lipid peroxidation (nmol g FM $\left.{ }^{-1}\right) ; \mathrm{H}_{2} \mathrm{O}_{2}$. Hydrogen peroxide $\left(\mu\right.$ mol g FM $\left.^{-1}\right)$; SOD - Superoxide dismutase $\left(\mathrm{U}\right.$ SOD mg prot ${ }^{-1}$ ); CAT - Catalase ( $\mu \mathrm{mol} \mathrm{min} \mathrm{mg}^{-1} \mathrm{mg}^{-1}$ protein); APX - Ascorbate peroxidase ( $\mu \mathrm{mol} \mathrm{min}{ }^{-1} \mathrm{mg}^{-1}$ protein); Sugarcane varieties RB966928, RB98710, RB855453, RB99395, RB867515, and RB855156, referred to in this study as RB1, RB2, RB3, RB4, RB5, and RB6, respectively; ${ }^{*}{ }^{* *}$ - Significant at $\mathrm{p} \leq 0.05$ and $\mathrm{p} \leq 0.01$ by $\mathrm{t}$-tests, respectively

be associated with the efficiency of plants in preventing damage to cell structures.

The results indicate that sugarcane variety and water and saline stress treatments all significantly affected the SOD, CAT, and APX activities $(\mathrm{p}<0.05)$ (Table 3$)$. The increase in the activity of the oxidative stress defense enzymes SOD, CAT, and APX showed a highly positive correlation (0.65. 0.96) (Table 2 ) in most varieties. Varieties RB5 and RB4 maintained a high RWC under the applied stresses. SOD acts on the dismutation of the superoxide radical $\left(\mathrm{O}_{2} \bullet\right)$, generating hydrogen peroxide $\left(\mathrm{H}_{2} \mathrm{O}_{2}\right)$, which in turn serves as a substrate for CAT and APX enzymes. Therefore, the coordinated activity of SOD with CAT and APX is crucial for the maintenance of the redox equilibrium, since it guarantees the effective elimination of oxidative molecules, preventing oxidative changes in several biological molecules (Shi et al., 2015). In the RB5 and RB4 varieties, enzymatic synchrony (Figures 1D, E, and F) guaranteed controlled levels of $\mathrm{H}_{2} \mathrm{O}_{2}$ and MDA (Figures $1 \mathrm{~B}$ and $\mathrm{C}$ ) in the isolated stress treatments (i.e. only water or saline stress). This result corroborates the results found by other authors (Cia et al., 2012; Morais et al., 2018).

Table 3. Analysis of variance (ANOVA) of the effects of sugarcane variety and water and saline stress treatments on superoxide dismutase (SOD), catalase (CAT), and ascorbate peroxidase (APX) activities in sugarcane plants

\begin{tabular}{lcccc}
\hline \multirow{2}{*}{ SV } & DF & $\begin{array}{c}\text { Superoxido } \\
\text { dismutase }\end{array}$ & Catalase & $\begin{array}{c}\text { Ascorbate } \\
\text { peroxidase }\end{array}$ \\
\cline { 3 - 5 } Variety - RB & 5 & $1772.5^{\star *}$ & $3467.4^{* *}$ & $1040082.1^{\star *}$ \\
Treatment - T & 3 & $3587.9^{* *}$ & $2193.1^{* *}$ & $626315.9^{* *}$ \\
RB x T & 15 & $559.9^{* *}$ & $336.6^{* *}$ & $115209.2^{* *}$ \\
Error & 72 & 64.0 & 36.8 & 5516.8 \\
Overall mean & & $38.14 \mathrm{U}$ & $42.7 \mu \mathrm{mol}$ & $860.7 \mu \mathrm{mol}$ \\
CV (\%) & & 20.9 & 14.2 & 8.6 \\
\hline
\end{tabular}

SV - Source of variation; DF - Degrees of freedom; MS - Mean square; ${ }^{*}{ }^{* *}$ - Significant at $\mathrm{p} \leq 0.05$ and $\mathrm{p} \leq 0.01$, respectively, according to the F-test; CV - Coefficient of variation
In situations of combined stress (water + saline), the RB5 variety stood out as the only variety to maintain high CAT and APX activities, ensuring low $\mathrm{H}_{2} \mathrm{O}_{2}$ concentrations, low lipid peroxidation, and high RWC values. These are associated with the maintenance of plant physiological processes and growth. In this respect, the increase in CAT and APX activities in the sugarcane plants of the RB867515 variety (referred to as RB5 in this study) exposed to saline stress, concomitantly with a lower reduction in fresh weight and chlorophyll concentrations, characterized this variety as more tolerant than the RB863129 variety (Willadino et al., 2011). In contrast, in the RB4 variety, a collapse in the antioxidative system occurred when plants were exposed to both water and saline stress, resulting in low CAT and APX activities (Figures $1 \mathrm{E}$ and F), and consequent increases in MDA and $\mathrm{H}_{2} \mathrm{O}_{2}$ concentrations (Figures $1 \mathrm{~B}$ and C). Antioxidant machinery inhibition may also lead to the accumulation of ROS, which can be relocated into specific cell compartments (Morais et al., 2019). It is likely that other peroxidases were also unable to cope with the excess ROS produced under the water + saline stress treatment.

An interesting pattern in the activity of antioxidant enzymes in response to stress was observed in the RB1 variety. Only SOD showed high activity (Figure 1D), probably due to the high production of $\mathrm{O}_{2}-{ }^{-}$caused by stress. The increase in SOD activity, however, was not accompanied by the same increase in the activities of CAT and APX enzymes (Figures $1 \mathrm{E}$ and $\mathrm{F}$ ), which explains the high concentrations of $\mathrm{H}_{2} \mathrm{O}_{2}$ observed (Figure 1C). The RB3 variety responded differently to the treatments that the other varieties, because it had high SOD, CAT, and APX enzymatic activities, even in the control treatment. Under stress conditions, the activity of these enzymes was higher, resulting in reduced $\mathrm{H}_{2} \mathrm{O}_{2}$ and MDA concentrations. However, the RWC was low, reaching a value of $56 \%$ under water + saline stress, which indicates a high transpiration rate in this variety. This assumption is confirmed, since this variety 
was considered sensitive to water stress based on the variables of stomatal conductance and leaf water potential, which were demonstrated to be appropriate physiological variables that can be used to differentiate between stress tolerance and sensitivity in sugarcane (Morais et. al., 2018).

For most of the studied varieties, effects of combined water + saline stress (T4) were more severe than the application of either of these stresses alone, which is reflected by greater reductions in RWC and higher concentrations of $\mathrm{H}_{2} \mathrm{O}_{2}$ and MDA. As for oxidative stress enzyme activity, there was a reduction in SOD and CAT activity in most sugarcane varieties when exposed to both water and saline stress, which suggests an inefficient response of the antioxidant system under these stress conditions, leading to high levels of $\mathrm{H}_{2} \mathrm{O}_{2}$, which can damage and inactivate SOD (Halliwell, 1974).

Overall, our results suggest that the damage caused by only water or saline stress is associated with oxidative stress, but it was evident that the combination of water and saline stress caused greater damage, and could even inhibit enzymatic action.

\section{Conclusions}

1. The patterns in the activities of antioxidative enzymes in the RB867515 and RB855156 sugarcane varieties exposed to water or saline stress showed a synchrony between the enzymatic antioxidant systems of superoxide dismutase, catalase, and ascorbate peroxidase in the regulation and detoxification of ROS produced in plant cells under conditions of environmental stress.

2. High lipid peroxidation associated with low relative water content may be an effective indicator of multiple stress sensitivity in sugarcane varieties.

3. The results found for the different sugarcane varieties suggest differential responses to the control of ROS and oxidative stress.

\section{ACKNOWLEDGMENTS}

We thank the Fundação de Amparo à Ciência e Tecnologia de Pernambuco (FACEPE) for funding the research (PBPG0924-5.01/10).

\section{Literature Cited}

Afzal, A.; Gulzar, I.; Shahbaz, M.; Ashraf, M. Water deficit-induced regulation of growth, gas exchange, chlorophyll fluorescence, inorganic nutrient accumulation and antioxidative defense mechanism in mungbean [Vigna radiata (L.) Wilczek]. Journal of Applied Botany and Food Quality, v.87, p.147-156, 2014.

Ajithkumar, I. P.; Panneerselvam, R. ROS scavenging system, osmotic maintenance, pigment and growth status of Panicum sumatrense Roth. under drought stress. Cell Biochemistry and Biophysics, v.68, p.587-595, 2014. https://doi.org/10.1007/ s12013-013-9746-x

Alexieva, V.; Sergiev, I.; Mapelli, S.; Karanov, E. The effect of drought and ultraviolet radiation on growth and stress markers in pea and wheat. Plant, Cell \& Environment, v.24, p.1337-1344, 2001. https://doi.org/10.1046/j.1365-3040.2001.00778.x
Aranda, I.; Cano, F. J.; Gascó, A.; Cochard, H.; Nardini, A.; Mancha, J. A.; López, R.; Sánchez-Gómez, D. Variation in photosynthetic performance and hydraulic architecture across European beech (Fagus sylvatica L.) populations supports the case for local adaptation to water stress. Tree Physiology, v.35, p.34-46, 2015. https://doi.org/10.1093/treephys/tpu101

Azevedo, R. A.; Alas, R. M.; Smith, R. J.; Lea, P. J. Response of antioxidant enzymes to transfer from elevated carbon dioxide to air and ozone fumigation, in leaves and roots of wild-type and catalase-deficient mutant of barley. Physiologia Plantarum. v.104, p.280-292, 1998. https://doi.org/10.1034/j.13993054.1998.1040217.x

Bezerra, R. R.; Silva, Ê. F. de F. e; Siqueira, G. M.; Dantas, D. da C.; Almeida, B. G. de; Silva, A. O. da. Least limiting water range in Spodosol and initial growth of sugarcane under soil bulk densities and salinities. Revista Brasileira de Engenharia Agrícola e Ambiental, v.23, p.833-839, 2019. https://doi.org/10.1590/18071929/agriambi.v23n11p833-839

Bradford, M. M. A rapid and sensitive for the quantitation of microgram quantities of protein utilizing the principle of proteindye binding. Analytical Biochemistry, v.72, p.248-254, 1976. https://doi.org/10.1016/0003-2697(76)90527-3

Cassaniti, C.; Romano, D.; Flowers, T. J. The response of ornamental plants to saline irrigation water. In: García-Garizábal, I. (ed.) Irrigation-water management, pollution and alternative strategies. InTech, 2012. Cap.9, p.132-158. https://doi. org/10.5772/31787

Cia, M. C.; Guimarães, A. C. R.; Medici, L. O.; Chabregas, S. M.; Azevedo, R. A. Antioxidant responses to water deficit by drought-tolerant and -sensitive sugarcane varieties. Annals of Applied Biology, v.161, p.313-324, 2012. https://doi.org/10.1111/ j.1744-7348.2012.00575.x

Ferreira, D. F. Estatística multivariada. Lavras: Editora UFLA, 2008. $662 p$.

Giannopolitis, C. N.; Ries, S. K. Superoxide dismutases: I Occurrence in higher plants. Plant Physiology, v.59, p.309-314, 1977. https://doi.org/10.1104/pp.59.2.309

Halliwell, B. Superoxide dismutase, catalase and glutathione peroxidase: Solutions to the problems of living with oxygen. New Phytologist, v.73, p.1075-1086, 1974. https://doi. org/10.1111/j.1469-8137.1974.tb02137.x

Havir, E. A.; Mchale, N. A. Biochemical and developmental characterization of multiple forms of catalase in tobacco leaves. Plant Physiology, v.84, p.450-455, 1987. https://doi.org/10.1104/ pp.84.2.450

Heath, R. L.; Packer L. Photoperoxidation in isolated chloroplast. I. Kinetics and stoichiometry of fatty acid peroxidation. Archives of Biochemistry and Biophysics, v.125, p.189-198, 1968. https:// doi.org/10.1016/0003-9861(68)90654-1

Hoagland, D.; Arnon, D. I. The water culture method for growing plants without soil. Berkeley: University of California - The College of Agriculture, California, 1950. 32p. Agriculture Experimental Station Circular, 347

Lata, C.; Jha, S.; Dixit, V.; Sreenivasulu, N.; Prasad, M. Differential antioxidative responses to dehydration induced oxidative stress in core set of foxtail millet cultivars. Protoplasma, v.248, p.817-828, 2011. https://doi.org/10.1007/s00709-010-0257-y 
Lira, R. M. de; Silva, Ê. F. de F. e; Barros, M. da S.; Gordin, L. C.; Willadino, L. G.; Barbosa, R. F. Water potential and gas exchanges in sugarcane irrigated with saline waters. Revista Brasileira de Engenharia Agrícola e Ambiental, v.22, p.679-682, 2018. https:// doi.org/10.1590/1807-1929/agriambi.v22n10p679-682

Lyra, G. B.; Silveira, E. L. da; Lyra, G. B.; Pereira, C. R.; Silva, L. D. B. da; Silva, G. M. da. Coefficient of the sugarcane crop at the initial stage of development in Campos dos Goytacazes, RJ. Irriga, v.1, p.102-113, 2012. https://doi.org/10.15809/irriga.2012v17n1p102

Morais, M. B. de; Barbosa-Neto, A. G.; Willadino, L.; Ulisses, C.; Calsa Junior, T. Salt stress induces increase in starch accumulation in duckweed (Lemna aequinoctialis, Lemnaceae): Biochemical and physiological aspects. Journal of Plant Growth Regulation, v.38, p.683-700, 2019. https://doi.org/10.1007/s00344-018-9882-z

Morais, M. B. de; Camara, T. R.; Ulisses, C.; Carvalho Filho, J. L. S.; Willadino, L. Multiple stresses on the oxidative metabolism of sugarcane varieties. Ciência Rural, v.48, p.1-8, 2018. https://doi. org/10.1590/0103-8478cr20141487

Nakano, Y.; Asada, K. Hydrogen peroxide is scavenged by ascorbate specific peroxidase in spinach chloroplast. Plant and Cell Physiology, v.2, p.867-880, 1981.

Oliveira, F. F. M.; Morais, M. B. de; Silva, M. E. de S.; Saraiva, Y. K. F.; Arruda, M. V. de M.; Silva, J. N. C. e; Albuquerque, C. C. de. Ecophysiological response of Lippia gracilis (Verbanaceae) to duration of salt stress. Ecotoxicology and Environmental Safety, v.178, p.202-210, 2019. https://doi.org/10.1016/j. ecoenv.2019.04.016

Palhares Neto, L.; Souza, L. M. de; Morais, M. B. de; Arruda, E.; Figueiredo, R. C. B. Q. de; Albuquerque, C. C. de; Ulisses, C. Morphophysiological and biochemical responses of Lippia grata Schauer (Verbenaceae) to water deficit. Journal of Plant Growh Regulation, v.39, p.26-40, 2019. https://doi.org/10.1007/s00344019-09961-6

Sewelam, N.; Kazan, K.; Schenk, P. M. Global plant stress signaling: Reactive oxygen species at the cross-road. Frontiers in Plant Science, v.7, p.1-21, 2016. https://doi.org/10.3389/ fpls.2016.00187
Shi, K.; Li, X.; Zhang, H.; Zhang, G.; Liu, Y.; Zhou, Y.; Xia, X.; Chen, $\mathrm{Z}$.; Yu, J. Guard cell hydrogen peroxide and nitric oxide mediate elevated $\mathrm{CO}_{2}$ induced stomatal movement in tomato. New Phytologist, v.208, p.342-353, 2015. https://doi.org/10.1111/ nph.13621

Silva, M. A.; Jifon, J. L.; Silva, J. A. G.; Sharma, V. Use of physiological parameters as fast tools to screen for drought tolerance in sugarcane. Brazilian Journal of Plant Physiology, v.19, p.193201, 2007. https://doi.org/10.1590/S1677-04202007000300003

Silva, V. N.; Souto, L. S.; Dutra Filho, J. A.; Souza, T. M. A.; Borges, C. H. A. Litter deposition in a savanna area preserved in the semiarid region of Paraíba, Brazil. Revista Verde de Agroecologia e Desenvolvimento Sustentável, v.10, p.21-25, 2015. https:/doi. org/10.18378/rvads.v10i2.3409

Silva-Pinheiro, J. da; Lins, L.; Souza, F. C.; Silva, C. E. M. da; Moura, F. de B. P.; Endres, L.; Justino, G. C. Drought-stress tolerance in three semi-arid species used to recover logged áreas. Brazilian Journal of Botany, v.39, p.1031-1038, 2016. https://doi. org/10.1007/s40415-016-0309-4

Soares, C.; Carvalho, M. E. A.; Azevedo, R. A.; Fidalgo, F. Plants facing oxidative challenges - A little help from the antioxidant networks. Environmental and Experimental Botany, v.161, p.4 -25, 2019. https://doi.org/10.1016/j.envexpbot.2018.12.009

Tayebimeigooni, A.; Awang, Y.; Mahmood, M.; Selamat, A.; Wahab, Z. Leaf water status, proline content, lipid peroxidation and accumulation of hydrogen peroxide in salinized Chinese kale (Brassica alboglabra). Journal of Food, Agriculture \& Environment, v.10, p.371-374, 2012.

Weatherley, P. E. Studies in the water relations of the cotton plant: I - The field measurements of water deficits in leaves. New Phytologist, v.49, p.81-97, 1950. https://doi. org/10.1111/j.1469-8137.1950.tb05146.x

Willadino, L.; Oliveira Filho, R. A. de; Silva Junior, E. A. da; Gouveia Neto, A.; Camara, T. R. Salinity stress in two varieties of sugar cane: Enzymes of the antioxidant system and chlorophyll fluorescence. Revistta Ciência Agronômica, v.42, p.417-422, 2011. https://doi.org/10.1590/S1806-66902011000200022 